\title{
Food, substrate or both? Decomposition of reed leaves (Phragmites australis) by aquatic macroinvertebrates in a large shallow lake (Lake Balaton, Hungary)
}

\author{
Kata Karádi-Kovács ${ }^{1,2 *}$, Géza Balázs Selmeczy ${ }^{1}$, Judit Padisák ${ }^{1,3}$ and Dénes Schmera ${ }^{4,5}$ \\ 1 Department of Limnology, University of Pannonia Egyetem str. 10, Hungary, H-8200 Veszprém, Hungary \\ 2 APEM Ltd., Cardiff Office, Gwaun Elai Business Campus, Llantrisant CF72 8XL, UK \\ 3 MTA-PE Limnoecology Research Group, Egyetem str. 10, Hungary, H-8200 Veszprém, Hungary \\ ${ }^{4}$ Section of Conservation Biology, Department of Environmental Sciences, University of Basel, St. Johanns-Vorstad 10, \\ CH-4056 Basel, Switzerland \\ 5 Balaton Limnological Institute, Centre for Ecological Research, Hungarian Academy of Sciences, Klebelsberg K. u. 3, \\ H-8237 Tihany, Hungary
}

Received 25 May 2014; Accepted 17 December 2014

\begin{abstract}
The aim of this study was to investigate the use and decomposition of reed leaves (Phragmites australis) by aquatic macroinvertebrates in a lake environment (Lake Balaton, Hungary). Natural and artificial leaves were exposed to separate the use of leaves as substrate and as food at different vertical positions. Although we recorded a low density of macroinvertebrates, mixed-effect models showed that natural leaves were colonized by a higher number of taxa and individuals than artificial leaves. Moreover, indicator species analysis identified two detritivorous species (Dikerogammarus villosus and Asellus aquaticus) as indicators of natural leaves. The obtained results suggest that macroinvertebrates use the leaves of reed not only as substrate but also as food. Leaf decay experiment showed that macroinvertebrates contribute to $87.5 \%$ of the total leaf litter decay. Leaf bags positioned at the surface were found to host less individuals but the decay rate was faster. The vertical position did not have an impact on the number of taxa or taxa composition. According to these results, macroinvertebrates represent an important component of detritus-based food webs in reed-vegetated littoral areas of the lake.
\end{abstract}

Key words: Lake Balaton / leaf bag / leaf decay / macroinvertebrates / substrate

\section{Introduction}

Although Phragmites australis is among the most productive plants, herbivores consume only a small portion of this production (Newman, 1991; Varga, 2003). Thus, reed belts are essentially detritus-based ecosystems (Bedford and Powell, 2005). At such sites, detritus is composed of shed leaves which accumulate mainly at the end of the growing season and dead stems which may remain standing for one or more years (Polunin, 1982).

A wide variety of aquatic macroinvertebrate taxa colonize the submerged detritus (Varga, 2001, 2003; Bedford and Powell, 2005). Observations that macroinvertebrate fauna of detritus in Phragmites stands include not only shredders (see definition in Cummins, 1973) but also other functional feeding groups (collectors, grazers, etc., see

\footnotetext{
*Corresponding author: kovacskata29@gmail.com
}

Varga, 2001; Kennedy et al., 2012) allow supposing that the detritus of reed provides both food and shelter or substrate for macroinvertebrates. In studying stream macroinvertebrate communities, Richardson (1992) hypothesized that some macroinvertebrate taxa use leaf bags only as substrate while other taxa use them both as substrate and food. For testing this hypothesis, he offered natural and artificial (non consumable) leaves and compared their macroinvertebrate communities. This technique is now routinely applied in stream ecology (Dobson et al., 1992; Dudgeon and Wu, 1999; Rowe and Richardson, 2001) and the obtained results showed that some macroinvertebrate taxa use leaf bags only as substrate, whereas others use leaf litter both as food and substrate. In spite of the massive amount of literature in stream ecology, we did not find any paper suggesting that aquatic macroinvertebrates use reed leaves as food or substrate in lakes. Moreover, the application of this 
technique is restricted to stream ecosystems while lakes were largely neglected (Klemmer and Richardson, 2013 is an exception). The above findings suggest that examining the role of macroinvertebrates in processing of reed may contribute to our general understanding of how detritus is used in reed belts of lake ecosystems and how detritus is used within lake food webs.

Identifying taxa using reed leaves both as food and substrate, however, does not necessarily provide a functional link between the decay of leaves and the contribution of macroinvertebrates to this process. This process can be examined by comparing the decay rate of leaves enclosed in coarse mesh (macroinvertebrates can enter and thus contribute to the decay rate) and that of leaves enclosed in fine mesh (macroinvertebrates cannot enter the bag and thus cannot contribute to the observed decay rate, see Gessner and Chauvet, 2002; Graca et al., 2007). Such studies showed that macroinvertebrates do have a significant contribution to the decay of reed leaves and the decay rates show strong spatial and temporal variations (van Dokkum et al., 2002; Bedford, 2005). Spatial variation is commonly interpreted as different geographic locations (van Dokkum et al., 2002), habitat types (Sangiorgio et al., 2006), or environmental gradients (Quintino et al., 2009), while vertical position has not received much attention (but see Sychra et al., 2010). We assumed that subsurface (top) and bottom positions contrast in abiotic habitat template (light conditions, wave action, oxygen concentration, etc.) and thus are inhabited by different macroinvertebrate communities, which finally result in a contrasting decay rate of reed leaves.

The general aim of this study was to investigate the substrate use and decomposition of reed leaves (P. australis (Cav.) Trin. ex Steud.) by aquatic macroinvertebrates in Lake Balaton, Hungary. Although Lake Balaton is a multi-purpose lake (used for water management, for recreational and sport activities, angling, etc.; Várkuti et al., 2008), its natural reed-vegetated areas provide an ideal opportunity for performing this study. In particular, we focused on the following questions: (1) which macroinvertebrate taxa occupy the decaying leaves of reed in Lake Balaton? (2) are there differences in species and/or abundance of macroinvertebrate assemblages colonizing reed leaves at different vertical positions? (3) do macroinvertebrates use the leaves of reed as substrate or as substrate and food or both? (4) do macroinvertebrates contribute to the decay of reed leaves?

\section{Material and methods}

\section{Study area}

With its $593 \mathrm{~km}^{2}$ surface area, Lake Balaton is the largest shallow lake in Central Europe (Crossetti et al., 2013). It has an average depth of $3.14 \mathrm{~m}$ and it is $77.9 \mathrm{~km}$ long and on average $7.2 \mathrm{~km}$ wide (Padisák, 1992). The lake was originally mesotrophic but underwent a rapid eutrophication in the 1960 s and 1970 s due to the increased nutrient load. By the 1980s, some basins in the lake had reached a permanently hypertrophic state. The implementation of rigorous management practices for the lake resulted in a decrease of the biologically available phosphorus by $50-60 \%$ and in a significant improvement of water quality (Padisák and Reynolds, 1998; Padisák et al., 2006; Istvánovics et al., 2007; Hajnal and Padisák, 2008). The littoral zone of the lake is mostly modified. Although widely distributed in the past, reed vegetated areas are now fragmented, with a total area of only $11 \mathrm{~km}^{2}$ (Erös et al., 2009; Tóth and Szabó, 2012).

The experiment was run in an area covered by excessive reed stands in the eastern basin of Lake Balaton in 2012. Four sampling sites were selected (sites A, B, C and D, see Fig. 1). Sites A and B were closer to the open water, whereas sites $\mathrm{C}$ and $\mathrm{D}$ were nearer to the shoreline. At site A, the water depth was about $43 \mathrm{~cm}$ and the bottom of the lake was covered by hard silt. The stems of reed were straight and stood densely. We did not observe any accumulation of organic debris. During the summer and autumn the depth of water decreased to some extent. At site B the water depth was $45 \mathrm{~cm}$ and the surface of the silt was hard and even. In summer, a dense vegetation of Eurasian water milfoil (Myriophyllum spicatum) appeared. At site $\mathrm{C}$ the water depth was $20 \mathrm{~cm}$ and the bottom was covered by hard silt. Finally at site D, the water depth was $26 \mathrm{~cm}$. There were some fragments of reed piled up at the base of the reed stems, but the thickness of this layer was less than $10 \mathrm{~cm}$. The layer had a loose texture and was consisted of large and fibrous pieces.

\section{Experimental design}

Our experiments combined two techniques. First, we used the technique developed by Richardson (1992) to examine whether macroinvertebrates use the leaves of reed ( $P$. australis) as food or microhabitat. This method was originally developed for studying the use of leaf accumulations by macroinvertebrates in headwater streams and is based on the comparison of macroinvertebrate communities colonizing artificial and natural leaves (Fig. 2). The basic idea is that natural leaves provide both food and substrate for macroinvertebrates, while artificial leaves only substrate. Our second technique examines the contribution of macroinvertebrates to leaf processing rate by comparing the decay rate of natural leaves enclosed in fine-mesh (macroinvertebrates excluded thus cannot contribute to the observed decay rate) and the decay rate of natural leaves enclosed in coarse-mesh (macroinvertebrates can populate and thus contribute to the decay rate). This technique is also routinely used in ecosystem studies (Graca et al., 2007; Boyero et al., 2011).

Leaves of reed were collected near the study sites in late autumn, 2011 and then were stored at a dry place. Before the start of the experiment, leaves were dried at $70^{\circ} \mathrm{C}$ until constant dry mass and then were cut into $13 \mathrm{~cm}$ long pieces. To examine whether macroinvertebrates use reed leaves as food or as substrate, bags $(10 \times 14 \mathrm{~cm}$, 

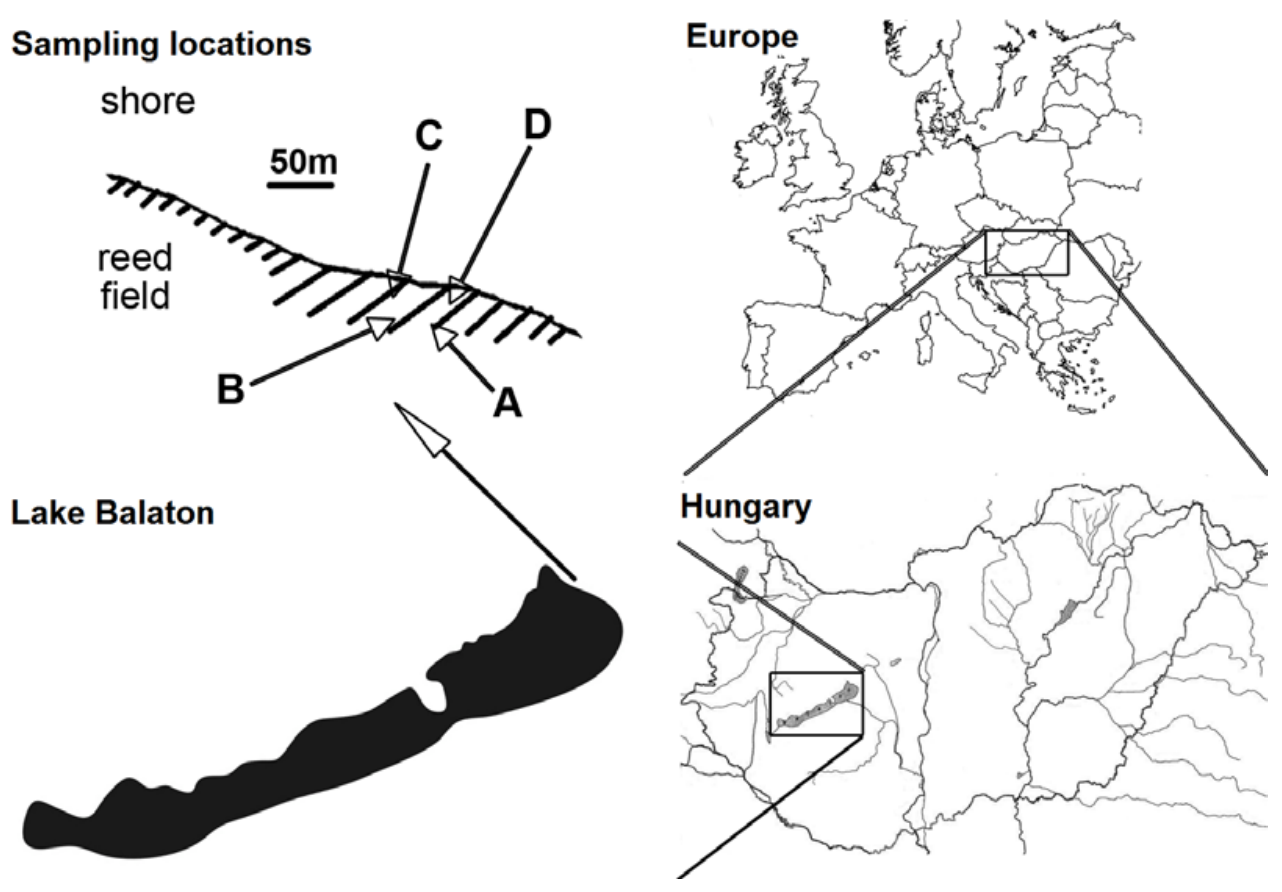

Fig. 1. The location of sampling sites.

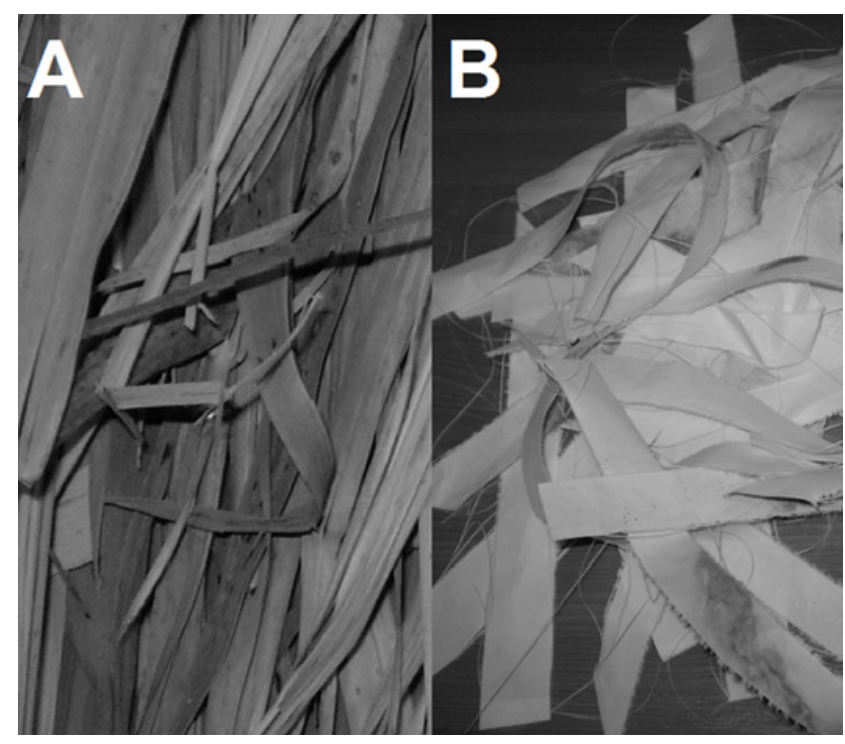

Fig. 2. Natural (A) and artificial (B) leaves.

mesh size $=10 \mathrm{~mm}$, hereafter referred to as coarse mesh) were filled with $5 \mathrm{~g}$ reed leaves (natural leaves) or pieces of sailcloth (type dacron) of similar size to mimic the substrate function of natural reed leaves, hereafter referred to as artificial leaves. To examine the contribution of macroinvertebrates to leaf processing we compared the decay rate of natural leaves $(5 \mathrm{~g})$ enclosed in coarse mesh (mesh size $=10 \mathrm{~mm}$ ) and in fine mesh (mesh size $=0.3 \mathrm{~mm}$ ). To study the effects of the vertical position of the bags, half of the bags were fixed at the top position (at the water surface), while half of the bags at the bottom position using a piece of basalt stone per bag.
The experiment was repeated three times: in spring (starting 10 March 2012), in summer (starting 12 June 2012) and in autumn (starting 5 September 2012) with four replicates. It follows that our experimental design used four sites (A, B, C and D), three treatments (artificial leaves in coarse mesh-bag, natural leaves in coarse meshbag and natural leaves in fine mesh-bag), two vertical positions (top and bottom), three seasons (spring, summer and autumn) and four replicates. At the beginning of the experiment, bags were fixed with small ropes at each site. In each season, site and position additional bags with fine mesh (four replicates/season/site/position) were used to assess the effect of leaching and handling (see further details in Bärlocher, 2007a, 2007b). These additional bags were removed on the second day of the experiment.

Fifty-seven days later (59 days after the start) the experiment was terminated. Similarly to other studies (Dobson, 1991; Heard et al., 1999; Bedford, 2004; Schindler and Gessner, 2009; Tiegs et al., 2009), we used only a single date for collecting macroinvertebrates and also for assessing decay rate. Consequently, it was meaningless to fit different statistical models to explain decay rate (see below).

Bags were collected and individually placed into plastic containers. Macroinvertebrates in coarse mesh bags were removed, preserved in $70 \%$ ethanol, counted and identified using the keys of Richnovszky and Pintér (1979), Gloer and Meier-Brook (1994), Eggers and Martens (2001) and Nesemann and Neubert (1999). Juvenile individuals were identified at family level only. We used the feeding habits of taxa described in Moog $(1995,2002)$ to separate shredders, as primary consumers of reed leaves, from other feeding groups primarily using leaf bags as substrate. 
When exposition was terminated, reed leaves were dried at $70^{\circ} \mathrm{C}$ to constant dry-mass and were weighed. To make our decay rates comparable with other studies we calculated not only the remaining leaf mass but also the exponential decay rate ( $k$, see Bärlocher, 2007b), which was adjusted for handling and leaching (Bärlocher, 2007b).

\section{Statistical analyses}

Mixed-effect models (MEMs) with site as the random factor were used to examine how the individual and joint effects of mesh size, the position of the bag and season influence leaf decay rate. Also MEMs with site as the random factor were used to test how leaf type, leaf position, season and the interaction of these factors influence taxa richness and abundance of lake macroinvertebrates. Taxa richness and abundance values were zero-inflated (several leaf bag contained zero taxa/individuals) and contained only integer values. We therefore fitted a MEM with Poisson distribution family using the Ime 4 package (Bates et al., 2013). Minimal adequate model was selected using Akaike Information Criteria (AIC).

Analysis of variance using distance matrices (called ADONIS in R), referred to also as "permutation MANOVA", "non-parametric MANOVA (Anderson, 2001; McArdle and Anderson, 2001) or "multivariate regression analysis of distance matrices" (Zapala and Schork, 2006) was used to test how leaf bag type (artificial versus natural leaves), the position of leaves (bottom versus top) and the season of the sampling (spring, summer or autumn) influence community composition. For the distance matrix, we used the Sorensen dissimilarity (for presence/absence data) and the Bray-Curtis dissimilarity (for abundance data, see formulae in Podani, 2000). ADONIS was run using the vegan package (Oksanen et al., 2013) and the statistical significance was tested by 999 permutations.

Indicator species analysis (INDVAL, Dufrene and Legendre, 1997) was run to identify characteristic taxa of leaf types (natural versus artificial), leaf positions (top versus bottom) and the three seasons. INDVAL analysis was run by the labdsv package (Roberts, 2012) using 1000 permutations. All statistical analyses were performed using R (R Core Team, 2013).

\section{Results}

\section{Community analyses}

Altogether 20 taxa (Table 1) were found among the 587 identified individuals. The dominant taxon was Dikerogammarus bispinosus Martynov, 1925 (26.7\% of the total number of individuals) followed by Dreissena polymorpha (Pallas, 1771) (24.4\%). The average number of taxa was 0.94 (range: $0-3$ ) in bags with artificial leaves and 1.61 (range: $0-7$ ) in bags with natural ones. The mean
Table 1. List of taxa.

\begin{tabular}{l}
\hline List of taxa \\
\hline Asellus aquaticus (Linnaeus, 1758) \\
Bithynia tentaculata (Linnaeus, 1758) \\
Caenis robusta (Eaton, 1884) \\
Cordulegaster heros (Theischinger, 1979) \\
Dendrocoelum lacteum (O.F. Müller, 1774) \\
Dikerogammarus bispinosus (Martynov, 1925) \\
Dikerogammarus villosus (Sowinsky, 1894) \\
Dreissena bugensis (Andrusov, 1897) \\
Dreissena polymorpha (Pallas, 1771) \\
Erpobdella nigricolis (Brandes, 1900) \\
Erpobdella octoculata (Linnaeus, 1758) \\
Glossiphonia complanata (Linnaeus, 1758) \\
Glossiphonia concolor (Apáthy, 1888) \\
Glossiphonia nebulosa (Kalbe, 1964) \\
Lithoglyphus naticoides (C. Pfeiffer, 1828) \\
Erpobdellidae \\
Chironomidae \\
Glossiphonidae \\
Gyrinidae \\
Oligochaeta
\end{tabular}

number of individuals varied between 0 and 13 individuals $($ mean $=1.98)$ in bags with artificial leaves, while between 0 and $48($ mean $=5.00)$ in bags with natural leaves. First we examined how macroinvertebrate taxa richness of leaf bags is influenced by the individual and joint effects of leaf type (natural versus artificial), leaf position (surface versus bottom) and season (spring, summer and autumn). AICbased model selection could not simplify the full-factorial model. The minimal adequate model showed the significant effect of leaf type (bags with natural leaves host more taxa $[$ mean $=1.614]$ than those with artificial leaves $[$ mean $=0.943]$ ) and the interaction of leaf type, leaf position and season (Table 2). This finding reveals that not only the leaf type but also the leaf position and the season influence the taxa richness of macroinvertebrates and the effect of any of these factors depends on the effect of the other factors (Fig. 3).

When examining macroinvertebrate abundance, the minimal adequate model showed that bags with natural leaves were occupied by more individuals $($ mean $=5.00)$ than bags with artificial leaves $($ mean $=1.98$, Table 2 ), leaf bags at the surface position contained less individuals $($ mean $=2.45)$ than bags at the bottom position (mean $=4.43$ ), and season had significant effect on macroinvertebrate abundance (mean number of individuals in spring, summer and autumn being 5.79, 3.04 and 1.53 respectively). Moreover, the significant two-way and three-way interactions in the minimal adequate model suggest that the effects of these factors are inter-dependent (Fig. 4).

ADONIS revealed that the season of the sampling had a significant impact on the taxa composition or on the abundance structure (Table 3) of lake macroinvertebrates, and the type of the leaves and the position of the leaf bags had no significant impact either on presence/absence or on abundance data (Table 3). This suggests that different 
Table 2. Summary of MEMs explaining the individual and joint effects of leaf type, leaf position and season on the taxa richness and abundance of macroinvertebrates.

\begin{tabular}{|c|c|c|c|c|c|}
\hline Response variable & Predictor & Estimate & S.E. & $z$-value & $P$ \\
\hline \multirow{11}{*}{ Taxa richness } & Leaf type (natural) & 0.614 & 0.285 & 2.153 & 0.031 \\
\hline & Leaf position (top) & -0.061 & 0.342 & -0.180 & 0.857 \\
\hline & Season (summer) & -0.570 & 0.388 & -1.472 & 0.141 \\
\hline & Season (autumn) & -0.549 & 0.388 & -1.417 & 0.156 \\
\hline & Leaf type (natural): Leaf position (top) & -0.807 & 0.469 & -1.722 & 0.085 \\
\hline & Leaf type (natural): Season (summer) & 0.428 & 0.471 & 0.909 & 0.363 \\
\hline & Leaf type (natural): Season (autumn) & -0.506 & 0.515 & -0.982 & 0.326 \\
\hline & Leaf position (top): Season (summer) & 0.772 & 0.510 & 1.512 & 0.130 \\
\hline & Leaf position (top): Season (autumn) & -0.874 & 0.683 & -1.279 & 0.201 \\
\hline & Leaf type (natural): Leaf position (top): Season (summer) & 0.232 & 0.661 & 0.350 & 0.726 \\
\hline & Leaf type (natural): Leaf position (top): Season (autumn) & 2.334 & 0.838 & 2.786 & 0.005 \\
\hline \multirow[t]{11}{*}{ Abundance } & Leaf type (natural) & 1.024 & 0.138 & 7.411 & $<0.001$ \\
\hline & Leaf position (top) & -0.824 & 0.231 & -3.564 & $<0.001$ \\
\hline & Season (summer) & -1.607 & 0.301 & -5.344 & $<0.001$ \\
\hline & Season (autumn) & -1.297 & 0.263 & -4.919 & $<0.001$ \\
\hline & Leaf type (natural): Leaf position (top) & -0.502 & 0.286 & -1.790 & 0.073 \\
\hline & Leaf type (natural): Season (summer) & 0.732 & 0.333 & 2.196 & 0.028 \\
\hline & Leaf type (natural): Season (autumn) & -0.559 & 0.331 & -1.692 & 0.091 \\
\hline & Leaf position (top): Season (summer) & 1.625 & 0.401 & 4.051 & $<0.001$ \\
\hline & Leaf position (top): Season (autumn) & 0.157 & 0.469 & 0.335 & 0.737 \\
\hline & Leaf type (natural): Leaf position (top): Season (summer) & -0.548 & 0.467 & -1.172 & 0.241 \\
\hline & Leaf type (natural): Leaf position (top): Season (autumn) & 1.183 & 0.559 & 2.117 & 0.034 \\
\hline
\end{tabular}

Significant factors are highlighted in bold.

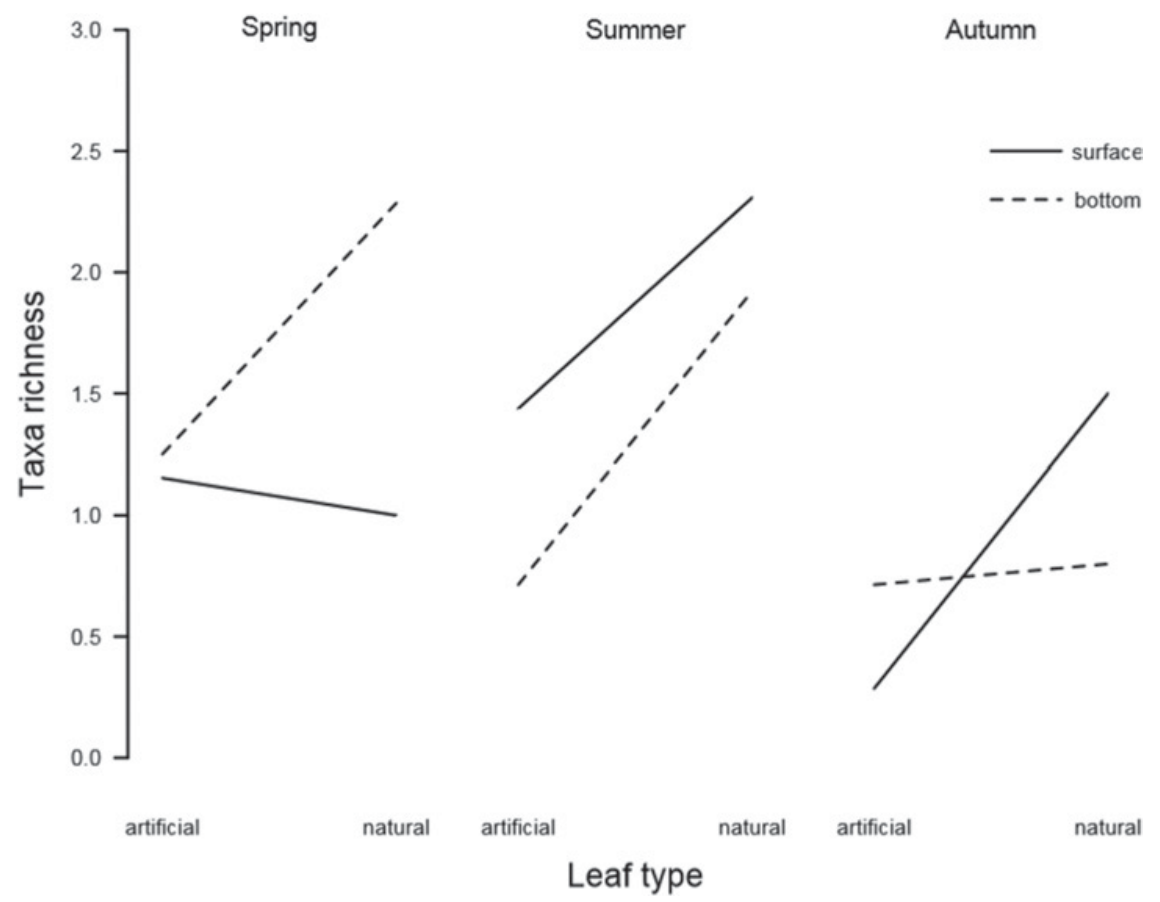

Fig. 3. Interaction plots showing the effects of leaf type (artificial versus natural) and leaf position (surface versus bottom) on taxa richness of macroinvertebrates in spring, summer and autumn.

macroinvertebrate assemblages colonized the leaf bags as the seasons progressed.

INDVAL analyses indicated that Dikerogammarus villosus (Sowinsky, 1894) (Indicator value $[\mathrm{IV}]=0.16$, $P=0.001)$, Asellus aquaticus (Linnaeus, 1758) $(\mathrm{IV}=0.10$, $P=0.037)$ and Erpobdella nigricollis Brandes, 1900 $(\mathrm{IV}=0.10, P=0.022)$ are indicators of natural leaves.
Artificial leaves had no indicator species. INDVAL did not find any indicator taxa of leaves at top or bottom position. Finally, INDVAL revealed that Erpobdella octoculata (Linnaeus, 1758) (IV =0.28, $P=0.001)$, D. bispinosus $(\mathrm{IV}=0.24, \quad P=0.009)$ and Bithynia tentaculata (Linnaeus, 1758) (IV $=0.07, P=0.043)$ are indicators of spring season, whereas Dreissena bugensis (Andrusov, 


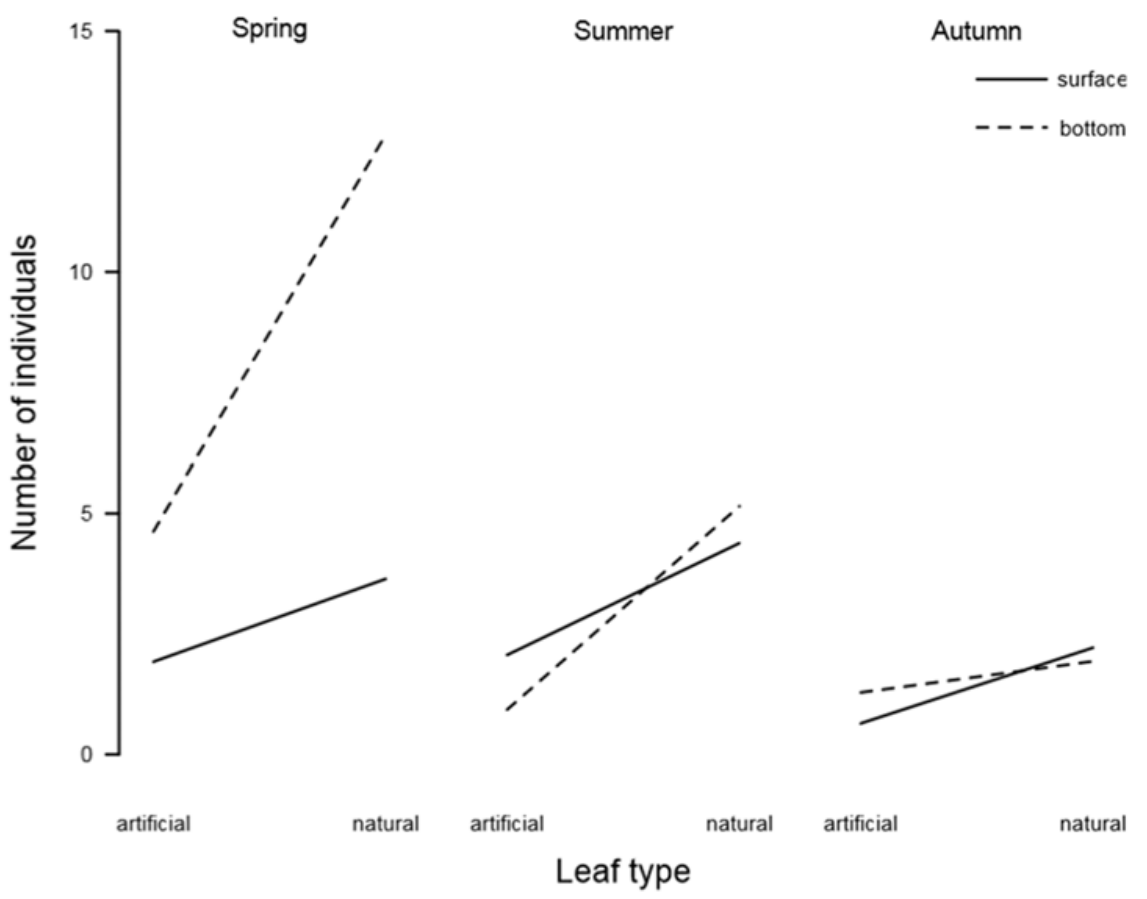

Fig. 4. Interaction plots showing the effects of leaf type (artificial versus natural) and leaf position (surface versus bottom) on the individuals of macroinvertebrates in spring, summer and autumn.

Table 3. Summary of analyses of variance using distance matrices (ADONIS) testing the individual and joint effects of leaf type, leaf position and season on community composition in presence/absence and abundance-based analyses.

\begin{tabular}{|c|c|c|c|c|c|c|c|}
\hline Analysis & Factors & Df & SS & MS & $F$ & $R^{2}$ & $P$ \\
\hline \multirow[t]{9}{*}{ Presence/absence } & Leaf type & 1 & 0.386 & 0.386 & 1.288 & 0.010 & 0.277 \\
\hline & Leaf position & 1 & 0.305 & 0.305 & 1.016 & 0.008 & 0.398 \\
\hline & Season & 2 & 4.775 & 2.389 & 7.969 & 0.126 & 0.001 \\
\hline & Leaf type: Leaf position & 1 & 0.058 & 0.058 & 0.192 & 0.001 & 0.953 \\
\hline & Leaf type: Season & 2 & 0.580 & 0.339 & 1.135 & 0.018 & 0.354 \\
\hline & Leaf position: Season & 2 & 0.643 & 0.321 & 1.073 & 0.016 & 0.387 \\
\hline & Leaf type: Leaf position: Season & 2 & 0.207 & 0.103 & 0.345 & 0.006 & 0.956 \\
\hline & Residuals & 103 & 30.856 & 0.299 & & 0.813 & \\
\hline & Total & 114 & 37.909 & & & 1.000 & \\
\hline \multirow[t]{9}{*}{ Abundance } & Leaf type & 1 & 0.518 & 0.518 & 1.517 & 0.012 & 0.132 \\
\hline & Leaf position & 1 & 0.426 & 0.426 & 1.246 & 0.009 & 0.269 \\
\hline & Season & 2 & 4.891 & 2.446 & 7.160 & 0.113 & 0.001 \\
\hline & Leaf type: Leaf position & 1 & 0.174 & 0.174 & 0.509 & 0.004 & 0.866 \\
\hline & Leaf type: Season & 2 & 0.707 & 0.353 & 1.034 & 0.016 & 0.412 \\
\hline & Leaf position: Season & 2 & 0.814 & 0.407 & 1.191 & 0.018 & 0.255 \\
\hline & Leaf type: Leaf position: Season & 2 & 0.403 & 0.201 & 0.589 & 0.009 & 0.896 \\
\hline & Residuals & 103 & 35.182 & 0.342 & & 0.816 & \\
\hline & Total & 114 & 43.115 & & & 1.000 & \\
\hline
\end{tabular}

Significant factors are highlighted in bold.

1897) $(\mathrm{IV}=0.25, \quad P=0.001), \quad E$. nigricollis $(\mathrm{IV}=0.20$, $P=0.001)$ and an unidentified Erpobdellidae sp. $(\mathrm{IV}=0.07, P=0.010)$ are indicators of summer. No taxa proved to be an indicator of autumn.

\section{Leaf decay experiments}

Leaf decay experiment showed that 64.4\% (range: $15.4-102.9 \%$ ) of the adjusted leaf mass remained in bags with small mesh size (mean decay rate $[k]=0.002$ ) whereas
$33.6 \%$ (range: $4.16-96.7 \%$ ) of the adjusted leaf mass in bags with large mesh size (mean decay rate $[k]=0.016$ ). The minimal adequate model showed that leaf decay is faster in bags with large mesh size $($ mean $=0.022)$ than in bags with small mesh size (mean $=0.008$, Table 4, Fig. 5) and that the effect of mesh size is season dependent (Table 4, Fig. 5). Moreover, model selection could not remove the three-way interaction of mesh size, leaf position and summer. This finding suggests that the effect of the studied three factors is inter-dependent even if the MEM indicated only a marginally significant effect (Table 4). 
Table 4. Summary of mixed-effect models explaining the individual and joint effects of mesh size, leaf position and season on the decay rate of reed litter.

\begin{tabular}{llrrrr}
\hline Response variable & Predictor & Estimate & S.E. & \multicolumn{1}{c}{$t$-value } \\
\hline Decay rate $(k)$ & Mesh size (coarse) & $\mathbf{0 . 0 0 7}$ & $\mathbf{0 . 0 0 3}$ & $\mathbf{2 . 5 6 1}$ & $\mathbf{0 . 0 1 1}$ \\
& Leaf position (top) & -0.001 & 0.003 & -0.482 & 0.630 \\
& Season (summer) & 0.002 & 0.003 & 0.672 & 0.502 \\
& Season (autumn) & 0.001 & 0.003 & 0.413 & 0.680 \\
& Mesh size (coarse): Leaf position (top) & 0.006 & 0.004 & 1.455 & 0.147 \\
& Mesh size (coarse): Season (summer) & $\mathbf{0 . 0 1 5}$ & $\mathbf{0 . 0 0 4}$ & $\mathbf{3 . 4 9 4}$ & $\mathbf{0 . 0 0 6}$ \\
& Mesh size (coarse): Season (autumn) & 0.001 & 0.004 & 0.147 & 0.883 \\
& Leaf position (top): Season (summer) & 0.006 & 0.004 & 1.401 & 0.163 \\
& Leaf position (top): Season (autumn) & 0.004 & 0.004 & 1.058 & 0.292 \\
& Mesh size (coarse): Leaf position (top): Season (summer) & -0.011 & 0.006 & -1.915 & 0.057 \\
& Mesh size (coarse): Leaf position (top): Season (autumn) & 0.001 & 0.006 & 0.207 & 0.836 \\
\hline
\end{tabular}

Significant factors are highlighted in bold.
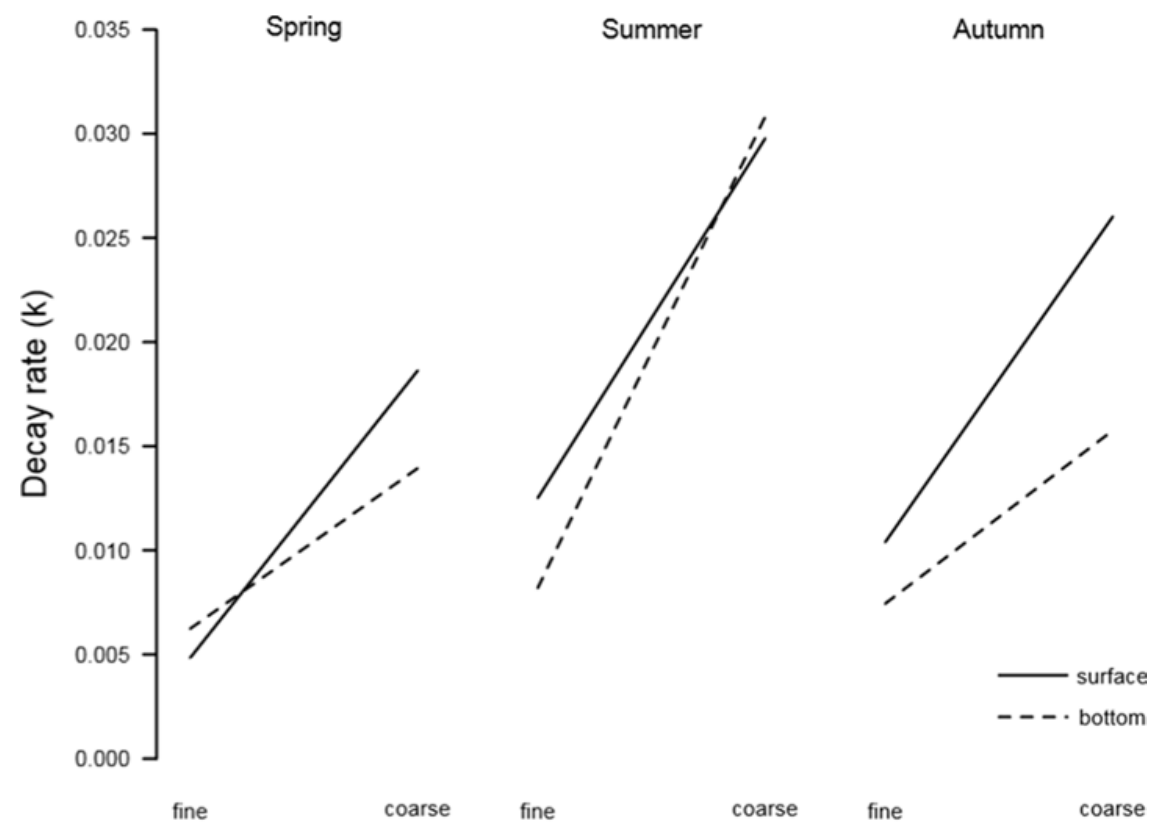

Mesh size

Fig. 5. Interaction plots showing the effects of mesh type (fine versus coarse) and leaf position (surface versus bottom) on the decay rate $(k)$ of reed leaves in spring, summer and autumn.

\section{Discussion}

In the present study, we examined the use and the decomposition of reed leaves by aquatic macroinvertebrates in Lake Balaton, Hungary, studying the macroinvertebrates colonizing reed leaves in different sample positions and examining the usage of leaves as substrate and food, as well as the impact on decomposition.

The total taxa richness in our experiment was relatively low compared to community surveys performed by hand nets in the same lake (Sipkay et al., 2007: 47 taxa) or by leaf bag technique in similar lakes (Varga, 2001: 31 taxa; Varga, 2003: 41 taxa; Bohman and Herrmann, 2006: 31 taxa; Bedford and Powell, 2005: 69 taxa). A possible explanation of this low taxa richness may be attributed to the high dominance of some Ponto-Caspian taxa at our sampling sites (D. bispinosus $26.7 \%$ and D. polymorpha,
$24.4 \%$ ), and the dominance of these species in Lake Balaton (Muskó et al., 2008) might depress natural taxa diversity (Schmidlin et al., 2012). As our research was designed to assess the use and the contribution of macroinvertebrates to the decomposition of reed, further studies are needed to clarify this relationship. Although we followed traditionally accepted protocols in site selection and during the experiment, similarly to the observed taxa richness, the number of individuals was also very low. Since this is the first leaf bag study in the lake that examines the contribution of macroinvertebrates to the decomposition of reed (in V.-Balogh et al., 2006 macroinvertebrates were not examined), comparisons with other studies are impossible.

Our results showed that top bags contain less individuals than those merged deeper. However, the decay rate at subsurface position was faster. This finding may reflect 
the effect of waves which impacts top bags more than bottom bags. Additionally, the amplitude of seiching at the part of the lake where the experiments were run may reach $40 \mathrm{~cm}$ (Józsa et al., 2012) further magnifying the effect of hydrodynamics.

Taxa composition was similar in surface and bottom bags, as was the number of taxa present. A possible explanation is that 2012 was a relative dry year and the vertical difference between surface and bottom bags was only about $40 \mathrm{~cm}$. This distance was probably not large enough to present significant differences in all community metrics, but some of our bottom bags were exposed to sludge deposition that decreased the abundance of macroinvertebrates. The negative relationship between decay rate and abundance regarding the vertical position of the bags is contradictory. It should however be noted that not only the abundance, but also the species richness and taxonomic composition of macroinvertebrates can have an effect on the decomposition rate (Jonsson and Malmqvist, 2000). A potential explanation can be the increased microbial activity on the surface as a result of higher available oxygen and light.

Our study showed a typical seasonal pattern in macroinvertebrate community structure: high taxa richness and abundance in spring-summer and a decreasing richness and abundance in autumn. ADONIS also revealed that community composition of macroinvertebrates shows seasonal pattern. This (together with other factors) resulted in a seasonal pattern in reed litter decay in agreement with observations by van Dokkum et al. (2002) and Bedford (2005).

Linear models showed that natural leaves in our study harbored more taxa and individuals than artificial leaves and indicator species analysis revealed that three taxa are indicators of natural leaves. The fact that two of these indicator taxa (D. villosus, A. aquaticus) are capable of feeding as a shredder suggests that the litter of reed leaves is used not only as substrate, but also as food. The third indicator taxon (E. nigricollis), in contrast, is a predator, which does not use the leaf litter as food, but might have a higher chance for getting a prey. According to our knowledge this study was the first that used the methodology of Richardson (1992) to show that the leaves of reed are more attractive to some taxa as leaves have more nutritional value (see also Dobson et al., 1992). Moreover, our leaf decay experiments showed that macroinvertebrates have significant contribution to the decay of reed leaves. According to our estimation, exponential decay coefficient $(\mathrm{k})$ without macroinvertebrates was 0.002 , while that with macroinvertebrates was 0.016 . The difference in decay rate in bags with small and large mesh-size showed that lake macroinvertebrates have a significant contribution to the leaf decay, i.e., macroinvertebrates contribute to $87.5 \%$ of the total leaf litter decay (disregarding leaching). The observed decomposition rate $(k=0.016)$ falls within the range of the published values for $P$. australis (between 0.004 [leaf in $5 \mathrm{~mm}$ mesh in wet habitat, Bedford, 2005] and 0.055 [summer, unprotected, see van Dokkum et al., 2002]).
In summary, examining macroinvertebrate community structure and the decay rate of submerged detritus in a reed-vegetated littoral area of Lake Balaton we found that, similarly to stream ecosystems (Boyero et al., 2009), macroinvertebrates use the decaying leaves of reed both as substrate and food and that aquatic macroinvertebrates are important components of the food web, playing an important role in ecosystem functioning. Our study also demonstrated that macroinvertebrates contribute significantly to the decay rate of reed litter in the littoral zone of Lake Balaton. Our findings suggest that the existence of a healthy macroinvertebrate community in reed-vegetated littoral areas of the lake is essential in maintaining the natural functioning of reed belts.

Acknowledgements. This research was supported by the OTKA K104279. We thank Jennifer Pinnion for correcting the English of the manuscript and Katalin Mikos for her support in the field work.

\section{References}

Anderson M.J., 2001. A new method for non-parametric multivariate analysis of variance. Austral Ecol., 26, 32-46.

Bärlocher F., 2007a. Leaching. In: Graca M.A.S., Bärlocher F. and Gessner M.O. (eds.), Methods to Study Litter Decomposition. A Practical Guide, Springer, Dordrecht, The Netherlands, 33-36.

Bärlocher F., 2007b. Leaf mass loss estimated by litter bag technique. In: Graca M.A.S., Bärlocher F. and Gessner M.O. (eds.), Methods to Study Litter Decomposition. A Practical Guide, Springer, Dordrecht, The Netherlands, 37-42.

Bates D., Maechler M. and Bolker B., 2013. lme4: linear mixed-effects models using S4 classes. R package version 0.999999-2, Available online at: http://CRAN.R-project.org/ package $=1 \mathrm{me} 4$.

Bedford A.P., 2004. A modified litter bag design for use in lentic habitats. Hydrobiologia, 529, 187-193.

Bedford A.P., 2005. Decomposition of Phragmites australis litter in seasonally flooded and exposed areas of a managed reedbed. Wetlands, 25, 713-720.

Bedford A.P. and Powell I., 2005. Long-term changes in invertebrates associated with the litter of Phragmites australis in a managed reedbed. Hydrobiologia, 549, 267-285.

Bohman I.M. and Herrmann J., 2006. The timing of wintergrowing shredder species and leaf litter turnover rate in an oligotrophic lake, SE Sweden. Hydrobiologia, 556, 99-108.

Boyero L., Ramirez A., Dudgeon D. and Pearson R.G., 2009. Are tropical streams really different? J. N. Am. Benthol. Soc., 28, 397-403.

Boyero L., Pearson R.G., Gessner M.O., Barmuta L.A., Ferreira V., Graca M.A.S., Dudgeon D., Boulton A.J., Callisto M., Chauvet E., Helson J.E., Bruder A., Albarino R.J., Yule C.M., Arunachalam M., Davis J.N., Figueroa R., Flecker A.S., Ramirez A., Death R.G., Iwata T., Mathooko J.M., Marthuriau C., Ives J.F.G., Moretti M.S., Jingut T., Lamothe S., M'Erimba C., Ratnarajah L., Schindler M.H., Castela J., Buria L.M., Cornejo A., Villanueva V.D. and West D.C., 2011. Global experiment suggests warming will 
not accelerate litter decomposition in streams but might reduce carbon sequestration. Ecol. Lett., 14, 289-294.

Crossetti L.O., Stenger-Kovács C. and Padisák J., 2013. Coherence of phytoplankton and attached diatom-based ecological status assessment in Lake Balaton. Hydrobiologia, 716, 87-101.

Cummins K.W., 1973. Trophic relations of aquatic insects. Annu. Rev. Entom., 18, 183-205.

Dobson M., 1991. An assessment of mesh bags and plastic leaf traps as tools for studying macroinvertebrate assemblages in natural leaf packs. Hydrobiologia, 222, 19-28.

Dobson M., Hildrew A.G., Ibbotson A. and Garthwaite J., 1992. Enhancing litter retention in streams. Do alter hydraulics and habitat area confound field experiments? Freshwat. Biol., 28, 71-79.

Dudgeon D. and Wu K.K.Y., 1999. Leaf litter in a tropical stream: food or substrate for macroinvertebrates? Arch. Hydrobiol., 146, 65-82.

Dufrene M. and Legendre P., 1997. Species assemblages and indicator species: the need for a flexible asymmetrical approach. Ecol. Monogr., 67, 345-366.

Eggers T.O. and Martens A., 2001. Bestimmungsschlüssel der Süßwasser-Amphipoda (Crustacea) Deutschlands. Lauterbornia Heft, 42, 68.

Erős T., Specziár A. and Bíró P., 2009. Assessing fish assemblages in reed habitats of a large shallow lake - a comparison between gillnet and electrofishing. Fish. Res., 96, 70-76.

Gessner M.O. and Chauvet E., 2002. A case for using litter breakdown to assess functional stream integrity. Ecol. Appl., $12,498-510$.

Gloer P. and Meier-Brook C., 1994. Süsswassermollusken. Ein Bestimmungsschlussel für die Bundesrepublik Deutschland, University of Hamburg, Tübingen.

Graca M.A.S., Bärlocher F. and Gessner M.O., 2007. Methods to Study Litter Decomposition. A Practical Guide, Springer, Dordrecht, The Netherlands, 329 p.

Hajnal É. and Padisák J., 2008. Analysis of long-term ecological status of Lake Balaton based on the ALMOBAL phytoplankton database. Hydrobiologia, 599, 227-237.

Heard S.B., Schultz G.A., Ogden C.B., and Griesel T.C., 1999. Mechanical abrasion and organic matter processing in an Iowa stream. Hydrobiologia, 400, 179-186.

Istvánovics V., Clement A., Somlyódy L., Specziár A., Tóth L.G. and Padisák J., 2007. Updating water quality targets for shallow Lake Balaton (Hungary), recovering from eutrophication. Hydrobiologia, 581, 305-318.

Jonsson M. and Malmqvist B., 2000. Ecosystem process rate increases with animal species richness: evidence from leafeating, aquatic insects. Oikos, 89, 519-523.

Józsa J., Rákóczi L. and Krámer T., 2012. Balaton Lake in Hungary. In: Bengtsson L. and Herschy R.W. (eds.), Encyclopedia of Lakes and Reservoirs, Springer, Netherlands, 91-95.

Kennedy E., Leff L.G. and deSzalay F.A., 2012. Herbiciding Phragmites australis: effects on litter decomposition, microbial biomass, and macroinvertebrate communities. Fund. Appl. Limn., 180, 309-319.

Klemmer A.J. and Richardson J.S., 2013. Quantitative gradient of subsidies reveals a threshold in community-level trophic cascades. Ecology, 94, 1920-1926.
McArdle B.H. and Anderson M.J., 2001. Fitting multivariate models to community data: a comment on distance-based redundancy analysis. Ecology, 82, 290-297.

Moog O., 1995. Fauna Aquatica Austriaca. 1. Auflage, Wasserwirtschafts - Kataster, Bundesministerium für Landund Forstwirtschaft, Wien.

Moog O., 2002. Fauna Aquatica Austriaca, Edition 2002. Wasserwirtschaftskataster, Bundesministerium für Landund Forstwirtschaft, Umwelt und Wasserwirtschaft, Wien.

Muskó I.B., Bence M. and Balogh C., 2008. Occurrence of a new Ponto-Caspian invasive species, Cordylophora caspia (Pallas, 1771) (Hydrozoa: Clavidae) in Lake Balaton (Hungary). Acta Zool. Acad. Svien. Hung., 54, 169-179.

Nesemann H. and Neubert E., 1999. Annelida, Clitellata, Süsswasserfauna von Mitteleuropa 6/2, Spektrum Akademisher Verlag GmbH, Heidelberg.

Newman R., 1991. Herbivory and detritivory on freshwater macrophytes by invertebrates: a review. J. North Am. Benthol. Soc., 10, 89-114.

Oksanen J., Blanchet F.G., Kindt R., Legendre P., Minchin P.R., O’Hara R.B., Simpson G.L., Solymos P., Stevens M.H.H. and Wagner H., 2013. Vegan: community ecology package. $\mathrm{R}$ package version 2.0-8, Available online at: http://CRAN. R-project.org/package $=$ vegan.

Padisák J., 1992. Seasonal succession of phytoplankton in a large shallow lake (Lake Balaton, Hungary) - a dynamic approach to ecological memory, its possible role and mechanisms. J. Ecol., 80, 217-230.

Padisák J. and Reynolds C.S., 1998. Selection of phytoplankton associations in Lake Balaton, Hungary, in response to eutrophication and restoration measures, with special reference to cyanoprokaryotes. Hydrobiologia, 384, 41-53.

Padisák J., Borics G., Grigorszky I. and Soróczki-Pintér É., 2006. Use of phytoplankton assemblages for monitoring ecological status of lakes within the Water Framework Directive: the assemblage index. Hydrobiologia, 553, 1-14.

Podani J., 2000. Introduction into the Exploration of Multivariate Biological Data, Backhuys Publisher, Leiden, The Netherlands.

Polunin N.V.C., 1982. Processes contributing to the decay of reed (Phragmites australis) litter in fresh waters. Arch. Hydrobiol., 94, 182-209.

Quintino V., Sangiorgio F., Ricardo F., Mamede R., Pires A., Freitas R., Rodrigues A.M. and Basset A., 2009. In situ experimental study of reed leaf decomposition along full salinity gradient. Estuar. Cost. Self Sci., 85, 497-506.

R Core Team, 2013. R: a Language and Environment for Statistical Computing, R Foundation for Statistical Computing, Vienna, Austria, Available online at: http:// www.R-project.org/.

Richardson J.S., 1992. Food, microhabitat, or both? Macroinvertebrate use of leaf accumulations in montane stream. Freshwat. Biol., 27, 169-176.

Richnovszky A. and Pintér L., 1979. Vizicsigák és kagylók (Mollusca) kishatározója. Vízügyi Hidrobiologia 6., Vízügyi Dokumentációs és Tájékoztatási Iroda, Budapest, 206 p.

Roberts D.W., 2012. labdsv: ordination and multivariate analysis for ecology. R package version 1.5-0, Available online at: http://CRAN.R-project.org/package = labdsv.

Rowe L. and Richardson J.S., 2001. Community responses to experimental food depletion: resource tracking by stream invertebrates. Oecologia, 129, 473-480. 
Sangiorgio F., Fonnesu A., Pinna M., Sebatta L. and Basset A., 2006. Influence of drought and abiotic factors on Phragmites australis leaf decomposition in the river Pula, Sardinia, Italy. J. Freshwat. Ecol., 21, 411-420.

Schindler M.H. and Gessner M.O., 2009. Functional leaf traits and biodiversity effects on litter decomposition in a stream. Ecology, 90, 1641-1649.

Schmidlin S., Schmera D. and Baur B., 2012. Alien molluscs affect the composition and diversity of native macroinvertebrates in a sandy flat of Lake Neuchatel, Switzerland. Hydrobiologia, 679, 233-249.

Sipkay C., Hufnagel L., Révész A. and Petrányi G., 2007. Seasonal dynamics of an aquatic macroinvertebrate assembly (Hydromorphological case study of Lake Balaton No2). Appl. Ecol. Environ. Res., 5, 63-78.

Sychra J., Zdenek A. and Petrivalska K., 2010. Distribution and diversity of littoral macroinvertebrates within extensive reed beds of a lowland pond. Ann. Limnol. - Int. J. Lim., 46, 281-289.

Tiegs S.D., Akinwole P.O. and Gessner M.O., 2009. Litter decomposition across multiple spatial scales in stream networks. Oecologia, 161, 343-351.

Tóth V. and Szabó K., 2012. Morphometric structural analysis of Phragmites australis stands in Lake Balaton. Ann. Limnol. - Int. J. Lim., 48, 241-251. van Dokkum H.P., Slijkerman D.M.E., Rossi L. and Costantini M.L., 2002. Variation in the decomposition of Phragmites australis litter in a monomictic lake: the role of gammarids. Hydrobiologia, 482, 69-77.

Varga I., 2001. Macroinvertebrates in reed litter. Int. Rev. Hydrobiol., 86, 573-585.

Varga I., 2003. Structure and changes of macroinvertebrate community colonizing decomposing rhizome litter of common reed at Lake Fertö/Neusiedler See (Hungary). Hydrobiologia, 506-509, 413-420.

Várkuti A., Kovács K., Stenger-Kovács C., and Padisák J., 2008. Environment consciousness of permanent inhabitants in shoreline cities and villages of Lake Balaton with special attention to issues connected to global climate change. Hydrobiologia, 599, 249-257.

V.-Balogh K., Présing M., Vörös L. and Tóth N., 2006. A study of the decomposition of reed (Phragmites australis) as a possible source of aquatic humic substances by measuring the natural abundance of stable carbon isotopes. Int. Rev. Hydrobiol., 91, 15-28.

Zapala M.A. and Schork N.J., 2006. Multivariate regression analysis of distance matrices for testing associations between gene expression patterns and related variables. Proc. Natl. Acad. Sci. USA, 103, 19430 19435. 